\title{
PENGARUH STRUKTUR MODAL, AKTIVITAS DAN EFISIENSI MODAL KERJA TERHADAP PROFITABILITAS SEKTOR INFRASTRUKTUR, UTILITAS DAN TRANSPORTASI YANG TERDAFTAR DI BURSA EFEK INDONESIA PERIODE 2014-2018
}

\author{
Puti Ayu Sriwananda ${ }^{1}$, Emianti Situmorang ${ }^{2}$, Puja Madwi ${ }^{3}$,Yenni Aprilia Sari ${ }^{4}$, Januardin $^{5}$ \\ FakultasEkonomi, Universitas Prima Indonesia \\ Putiayu12sriwananda@gmail.com¹, Emiantisitumorang@gmail.com², Pujamadwi1909@gmail.com³ \\ Yenniaprilia98@gmail.com ${ }^{4}, \underline{\text { Januardin@unprimdn.ac.id }}{ }^{5}$
}

\begin{abstract}
The object of this study was to analyze the effect of Capital Structure, Activities and Working Capital Efficiency on the Profitability of the Infrastructure, Utilities and Transportation sectors in the Indonesia Stock Exchange for the 2014-2018 Period. This research was conducted on 79 companies. There are 19 samples with purposive sampling technique. From the results of the analysis. known phenomena at PT.SamuderaIndonesia total debt in 2014-2015 has decreased but net income has also decreased. In the State Gas Company (Persero), total assets in 2014-2015 experienced an increase but their net income decreased. And in the Indonesian telecommunications company sales in 2017-2018 have increased but their net profit has decreased. This phenomenon is not in accordance with the prevailing theory. The method for testing classical assumptions is Multiple Linear Regression Analysis. The results of the simultaneous study of Capital Structure, Activities and Working Capital Efficiency together have a significant positive effect on profitability. Partially, the Capital Structure and Activities have a significant positive effect on profitability, while the efficiency of working capital has a significant negative effect on profitability. Based on the results of the analysis it is suggested that companies maintain the Capital Structure and Activities of the company and be more efficient in managing Working Capital.
\end{abstract}

Keywords: Activities, Working Capital Efficiency, Profitability, Capital Structure.

\section{PENDAHULUAN}

Di dalam dunia globalisasi, kompetisi yang terjadi antara banyak perusahaan berkembang secara signifikan. Oleh karena itu, pembangunan transportasi, utilitas dan juga infrastruktur sangat membantu perusahaan. Sekarang presiden gencar-gencarnya membangun infrastruktur di berbagai daerah. Pembangunan ini pasti memberikan profitabilitas yang baik bagi perusahaan maupun negara. Profitabilitas adalah kapasitas yang ada dalam suatu perusahaan atau badan usaha dalam mendapatkan laba atau keuntungan selama periode waktu tertentu.

Sektor infrastruktur, utilitas dan transportasi merupakan salah satu dari beberapa jenis sektor yang terdaftarkan pada Bursa Efek Indonesia (BEI). Perusahaan sector ini adalah beberapa jenis perusahaan tertentu yang bergerak di bidang penyediaan energi, sarana telekomunikasi dan transportasi, serta infrastruktur dan jasa penunjangnya. Infrastruktur merupakan fasilitas-fasilitas fisik yang dibutuhkan oleh publik sebagai kebutuhan dasar fisik pengorganisasian dalam lingkup sosial dan ekonomi.

Teknologi yang digunakan dalam transportasi menjadi tolak ukur kemajuan dari suatu negara. Semakin canggih transportasinya maka semakin pesat pula pertumbuhan ekonomi di negara tersebut karena melalui transportasilah semua sumber daya dan kekayaan suatu negara dapat diproses dengan cepat dan tepat waktu.

Sektor transportasi, utilitas dan infrastuktur mempunyai berbagai subsector, diantaranya ialah:

1. Subsektor konstruksi non bangunan

2. Subsektor energi

3. Subsektor telekomunikasi

4. Subsektor bandara, pelabuhan, jalan tol dan seterusnya 


\section{Subsektor transportasi}

Salah satu dari beberapa komponen yang sangat mendasar untuk memulai suatu badan usaha atau perusahaan adalah ketersediaan modal. Struktur modal ialah komparasi antara modal sendiri dengan total utang dalam pengoperasian suatu aktivitas dalam sebuah perusahaan. Struktur modal bias ditinjau berdasarkan pada nilai dari Debt toEquity Ratio (DER). Oleh karena itu, Aktivitas perusahaan menentukan berkurang atau bertambahnya modal. Aktivitas perusahaan juga berpengaruh dalam menghasilkan laba. Kemampuan aktivitas dapat dilihat dari nilai perputaran total asset (Total assets turn over) atau biasa disebut TATO. TATO adalah indicator untuk mengukur keefektifan perputaran total asset perusahaan yang diukur dari volume penjualannya.

Selainitu, modal kerja harus efisien karena lebih atau kurangnya modal kerja dapat membawa dampak buruk terhadap suatu perusahaan. Efisiensi pada modal kerja bias ditinjau berdasarkan pada Working Capital Turn Over (WCTO). WCTO adalah indicator untuk mengukur peredaran modal kerja dalam satu periode siklus kas yang diawali dari kas yang selanjutnya untuk diijadikan sebagai penanaman modal kedalam komponen modal kerja sampai berubah kembali menjadi kas perusahaan. Jika waktu peredaran modal kerja tersebut cepat, dengan demikian penggunaan modal suatu perusahaan akan menjadi lebih efisien.

Berdasarkan analisis terhadap laporan keuangan Sektor transportasi, utilitas dan infrastuktur yang terdaftarkan pada Bursa Efek Indonesia untukperiode waktu mulai tahun 2014 sampai dengan tahun 2018, diketahui fenomena pada perusahaan Samudera Indonesia Tbk yaitu total hutang ditahun 2014-2015 mengalami penurunan dari Rp.4.119.526.896.342 menjadi Rp.3.826.219.730.520 tetapi laba bersihnya juga mengalami penurunan dari Rp.264.480.656.154 menjadi Rp.135.571.179.040, dimana menurut teori seharusnya jika total hutang turun maka laba bersih seharusnya naik.

Pada perusahaan Gas Negara (Persero) Tbk yaitu total aktiva ditahun 2014-2015 mengalami peningkatan dari Rp.77.326.990.202.319 menjadi Rp.88.592.103.640.040 tetapi laba bersihnya mengalami penurunan dari Rp.9.301.780.882.680 menjadi Rp.5.493.631.450.560, dimana menurut teori seharusnya jika total aktiva naik maka laba bersih seharusnya naik.

Pada perusahaan Telekomunikasi Indonesia Tbk yaitu penjualan ditahun 2017-2018 mengalami peningkatan dari Rp.128.256.000.000.000 menjadi Rp.130.784.000.000.000 tetapi laba bersihnya mengalami penurunan dari Rp.32.701.000.000.000 menjadi Rp.26.979.000.000.000, dimana menurut teori seharusnya jika penjualan naik maka laba bersih seharusnya naik.

\section{KAJIAN LITERATUR}

\section{Struktur Modal}

Berdasarkan pada uraian penjelasan oleh Dr. R. AgusSartono (2017:225) menjelaskan bahwa struktur modal ialah suatu neraca keseimbangan dari jumlah hutang jangka waktu pendek yang memiliki sifat yang permanen dan sedangkan jangka waktu yang panjang ialah saham biasa dan juga saham preferen. Berdasarkan pada uraian penjelasan oleh Irham Fahmi (2018:187) menjelaskan bahwa struktur modal dapat dengan menggunakan indicator sebagaimana berikut ini:

Debt to Equity Ratio $=\frac{\text { TotalLiabilities }}{\text { Stockholder'sEquity }}$

\section{Aktivitas}

Berdasarkan pada uraian penjelasan oleh Kasmir (2018:172) menjelaskan bahwa rasio aktivitas ialah rasio yang memiliki fungsi sebagai pengukuran terhadap efektivitas yang dimiliki oleh perusahaan dalam mempergunakan aktiva yang terdapat pada perusahaan tersebut. Salah satu jenis rasio aktivitas adalah Total Assets Turn Over dengan indicator penghitungannya sebagai berikut:

Total Assets Turnover $=\frac{\text { Penjualan(Sales) }}{\text { TotalAktiva(TotalAssets) }}$

\section{Modal Kerja}

Berdasarkan pada uraian penjelasan oleh Irham Fahmi (2018:100) mennjelaskan bahwa modal kerja ialah sebagai bentuk penanaman modal pada suatu perusahaan tertentu yang berupa piutang, persedian, sekuritas, dan juga aktiva yang jangka pendek. Berdasarkan pada uraian penjelasan oleh Dr. 
R. AgusSartono (2017:393) menjelaskan bahwa modal kerja dapat dilaksanakan penghitungan dengan cara mempergunakan indicator sebagaimana berikut ini:

Perputaran Modal Kerja $=\frac{\text { Penjualan }}{\text { Rata-ratakas }}$

\section{Profitabilitas}

Berdasarkan pada uraian penjelasan oleh Kasmir (2018:196) menjelaskan bahwa rasio profitabilitas ialah suatu rasio yang memiliki kegunaan untuk melaksanakan penilaian terhadap kapasitas yang dimiliki oleh suatu perusahaan atau badan usaha dalam upaya untuk mendapatkan laba atau keuntungan.

Modal kerja dapat dilaksanakan penghitungan dengan cara mempergunakan indicator sebagaimana berikut ini:

Return on Equity $=\frac{\text { EarningAfterInterest } \wedge \text { Tax }}{\text { Equity }}$

\section{Pengaruh Struktur Modal Terhadap Profitabilitas}

Berdasarkan pada uraian penjelasan oleh Sri Dwi Ari Ambarwati (2010:2) menjelaskan bahwa struktur modal adalah perimbangan atau kombinasi antara modal sendiri dengan hutang (saham biasa dan saham preferen) yang dipergunakan oleh suatu perusahaan dalam upaya untuk memperoleh jumlah nominal modal tertentu.

Hal ini mengandung arti bahwa suatu perusahaan diwajibkan untuk melaksanakan pengambilan suatu keputusan yang berkenaan dengan modal yang optimal, supaya antara ekuitas dengan utang merupakan suatu gabungan yang paling ideal dalam mendapatkan laba atau keuntungan untuk perusahaan, yang pada akhirnya mampu mengoptimbalkan keuntungan yang diraih oleh suatu perusahaan.

\section{Pengaruh Aktivitas Terhadap Profitabilitas}

Berdasarkan pada uraian penjelasan oleh kasmir (2012:85) menjelaskan bahwa TATO (Total Asset Turnover) ialah suatu rasio yang memperlihatkan besaran dari jumlah penjualan yang dihasilkan oleh tiap rupiah dari aktiva yang ada pada perusahaan tersebut. Rasio ini akan mendeskripsikan mengenai besaran efisiensi dari perusahaan dalam mempergunakan asset yang ada di dalam aktivitas pengoperasionalan suatu perusahaan.

Jika rasio tersebut tinggi, dengan demikian memperlihatkan bahwa perusahaan tersebut sudah dapat mengoptimalkan aktiva yang dimiliki oleh perusahaan dalam menaikkan tingkat kuantitas perusahaan. Dengan adanya tingkatan penjualan tinggi tersebut, dengan demikian perusahaan tersebut dapat memperoleh keuntungan atau laba yang baik juga.

\section{Pengaruh Efisiensi Modal Kerja Terhadap Profitabilitas}

Berdasarkan pada uraian penjelasan oleh Sri Dwi Ari Ambarwati (2010:111) menjelaskan bahwa aktiva lancar yang dipergunakan dalam kegiatan pengoperasionalan perusahaaan yang membutuhkan daya kelola yang bagus oleh manajer, dengan demikian kegiatan pengoperasionalan perusahaan akan menjadi lebih efisien dan juga optimal atau bias dikatakan bahwa modal kerja ialah modal yang semestinya dimiliki oleh suatu perusahaan, dengan demikian kegiatan pengoperasionalan perusahaan akan menjadi lebih efisien dan lancer dalam upaya untuk memperoleh keuntungan atau laba yang didapatkan. 


\section{KerangkaKonseptual}

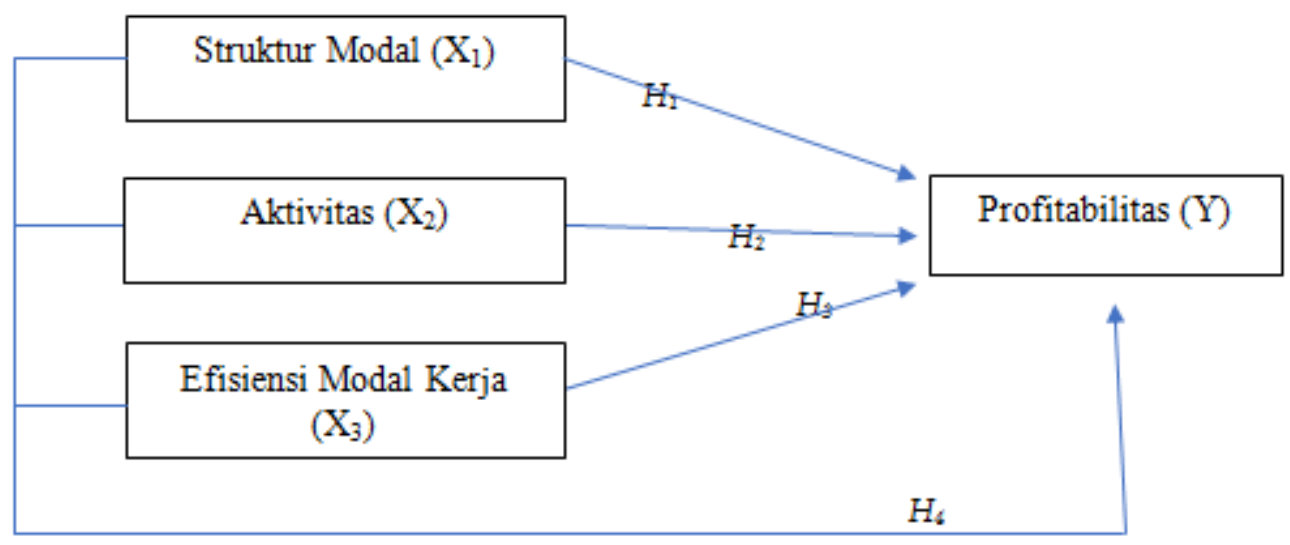

\section{METODE PENELITIAN}

\section{Tempat dan Waktu Penelitian}

Penelitian ini dilakukan di sector infrastruktur, utilitas dan transportasi yang didaftarkan pada Bursa Efek Indonesia (BEI) untuk periode waktu tahun 2014 sampai dengan tahun 2018 dengan cara mempergunakan data sekunder yang didapatkan dengan akses pada situs www.idnfinancials.com dan www.idx.co.id serta waktu penelitian dilakukan pada bulan JanuariApril 2019.

\section{Populasi dan Sampel}

Dalam penelitian ini, populasi yang digunakan ialah ada sekitar 79 perusahaan serta sebanyak 19 perusahaan memenuhi kriteria untuk menjadi sampel dalam penelitian. Dalam pengambilan sampel, teknik yang dipergunakan ialah dengan metode purposive sampling yakni suatu metode yang berguna dalam menentukan jumlah sampel dengan cara mempertimbangkan keseimbangan sampel.

\section{Uji Asumsi Klasik}

Uji Normalitas

Pengujian normalitas adalah uji yang memiliki tujuan untuk melaksanakan pengujian terhadap permodelan regresi yang dipergunakan apakah variabel residual atau pengganggu tersebut sudah berdistrisibusi normal atau belum. Dalam upaya untuk mengetahui apakah variabel residual atau pengganggu tersebut sudah berdistrisibusi normal ialah dengan cara melaksanakan penganalisaan dengan mempergunakan grafik histogram dan juga Normal P-plot of Regression Standarized Residual.

\section{Uji Multikolinieritas}

Pengujian multikolinearitas adalah uji yang memiliki tujuan untuk melaksanakan pengujian terhadap permodelan regresi yang dipergunakan apakah terdapat korelasi diantara variabel bebas atau independen.

Jika tidak terdapat hubungan korelasi diantara variabel bebas berarti dapat dikatakan bahwa model regresi tersebut dinyatakan bagus. Terjadinya kondisi multikolinearitas ini dapat diketahui berdasarkan pada nilai tolerance dan VIF (Variance Inflation Factor). Apabila nilai tolerance $>0,1$ dan sedangkan nilai $\mathrm{VIF}<10$, dengan demikian dinyatakan bahwa permodelan regresi tersebut tidak ada gejala multikolinearitas.

\section{Uji Autokorelasi}

Pengujian autokorelasi adalah uji yang memiliki tujuan untuk melaksanakan pengujian terhadap permodelan regresi yang dipergunakan apakah terdapat hubungan korelasi antara 
kesalahan pengganggu pada periode $\mathrm{t}$ dengan kesalahan pengganggu pada periode $\mathrm{t}-1$ (sebelumnya). Terjadinya autokorelasi dapat dideteksi dengan Durbin-Watson Test.

\section{Uji Heteroskedastisitas}

Uji heteroskedastisitas adalah uji yang memiliki tujuan untuk melaksanakan pengujian terhadap permodelan regresi yang dipergunakan apakah terdapat ketidaksamaan variance dari residual satu pengamatan ke pengamatan yang lain. Permodelan regresi yang bagus ialah jika tidak terdapat heteroskedastisitas. Uji heteroskedastisitas dapat dilihat dengan cara mempergunakan pengujian scatterplot dan juga pengujian glejser.

\section{PengujianHipotesis}

\section{Uji Parsial (Uji t)}

Uji t digunakan untuk menunjukkan apakah semua variabel bebas memberikan sumbangan pengaruh secara parsial (individu) terhadap variabel terikat. Hipotesis untuk uji t menggunakan nilai signifikan sebesar 0,05 .

\section{Uji Simultan (Uji F)}

Uji F memiliki tujuan untuk menunjukkan apakah semua variabel bebas memberikan sumbangan pengaruh secara simultan terhadap variable terikat. Hipotesis untuk uji F menggunakan nilai signifikan senilai 0,05 .

\section{HASIL PENELITIAN DAN PEMBAHASAN}

\section{Uji Asumsi Klasik}

Uji Normalitas

A. Grafik Histogram

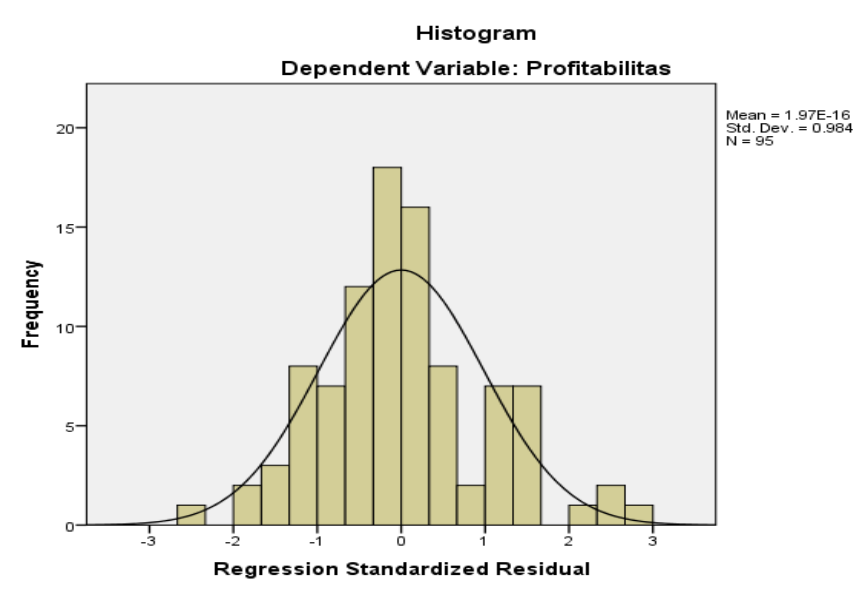

\section{Gambar 1. Grafik Histogram}

Sumber: Data diolah SPSS

Berdasarkan gambar 1, analisis grafik histogram memperlihatkan histogram berbentuk lonceng serta tidak terlalu kekanan dan tidak terlalu kekiri yang berarti data berdistribusi normal. 
B. Normal probably plots

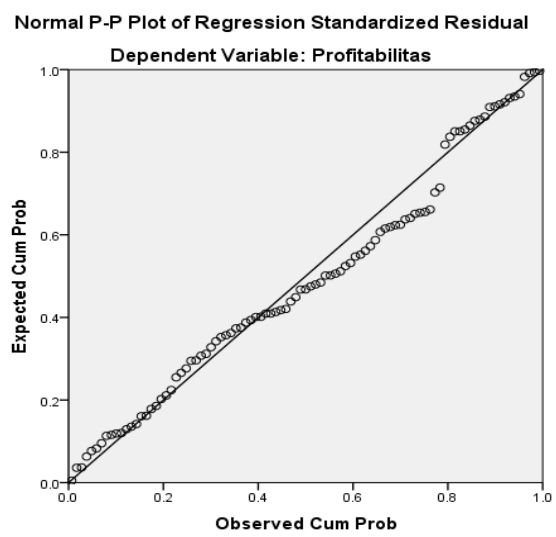

Gambar 2. Normal probably plots

Sumber: Data diolah SPSS

Berdasarkan gambar 2, analisis p-plots uji normalitas memperlihatkan titik yang mengikuti garis diagonal dan penyebaran dekat dengan garis diagonal. Gambar tersebut menunjukan bahwa data penelitian ini berdistribusi normal.

\section{Uji Multikoliniearitas}

Tabel 1. Hasil Uji Multikoliniearitas

Coefficientsa

\begin{tabular}{|c|c|c|c|}
\hline \multirow[t]{2}{*}{ Model } & \multicolumn{3}{|c|}{ Collinearity Statistics } \\
\hline & Tolerance & VII & \\
\hline (Constant) & & & \\
\hline $\begin{array}{l}\text { Struktur } \\
\text { Modal }\end{array}$ & .959 & & 1.042 \\
\hline Aktivitas & .954 & & 1.048 \\
\hline $\begin{array}{l}\text { Efisiensi } \\
\text { Modal Kerja }\end{array}$ & .994 & & 1.006 \\
\hline
\end{tabular}

a. Dependent Variable: Profitabilitas

\section{Sumber: Data diolah SPSS}

Ini lebih tinggi dibandingkan dengan 0,10 dan sedangkan nilai dari VIF ialah senilai 1,042, dan ini lebih rendah dibandingkan dari 10. Aktivitas $\left(\mathrm{X}_{2}\right)$ memiliki nilai tolerancese nilai 0,954 dan ini lebih tinggi dibandingkan dengan 0,10 dan dan sedangkan nilai dari VIF ialah senilai 1,048 dan ini lebih rendah dibandingkan dari 10 . Efisiensi modal kerja $\left(X_{3}\right)$ memiliki nilai tolerance senilai 0,994 dan ini lebih tinggi dibandingkan dengan 0,10 dan sedangkan nilai dari VIF ialah senilai 1,006 dan ini lebih rendah dibandingkan dari 10. Dengan demikian bias ditarik suatu kesimpulan bahwa tidak ada multikolinieritas antara ketiga variable bebas (independent) karena hasil memenuhi syarat uji multikolinieritas 


\section{Uji Autokorelasi}

Tabel 2. Hasil Uji Autokorelasi

Model Summaryb

\begin{tabular}{|l|r|r|r|r|r|}
\hline Model & \multicolumn{1}{|c|}{$\mathrm{R}$} & R Square & $\begin{array}{c}\text { Adjusted R } \\
\text { Square }\end{array}$ & $\begin{array}{c}\text { Std. Error of the } \\
\text { Estimate }\end{array}$ & Durbin-Watson \\
\hline 1 & $.704^{\mathrm{a}}$ & .495 & .479 & .1170123 & 1.034 \\
\hline
\end{tabular}

a. Predictors: (Constant), Efisiensi Modal Kerja, Struktur Modal, Aktivitas

b. Dependent Variable: Profitabilitas

Sumber: Data diolah SPSS

Dari tabel 2 didapatkan hasil dari nilai durbin Watson senilai 1,034. Pengujian autokorelasi dilakukan dengan menggunakan $-2 \leq \mathrm{DW} \leq 2$. Didapatkan hasil pengukurannya ialah $-2 \leq 1,034 \leq 2$, dapat disimpulkan tidak terdapat autokorelasi.

\section{Uji Heterokedastisitas}

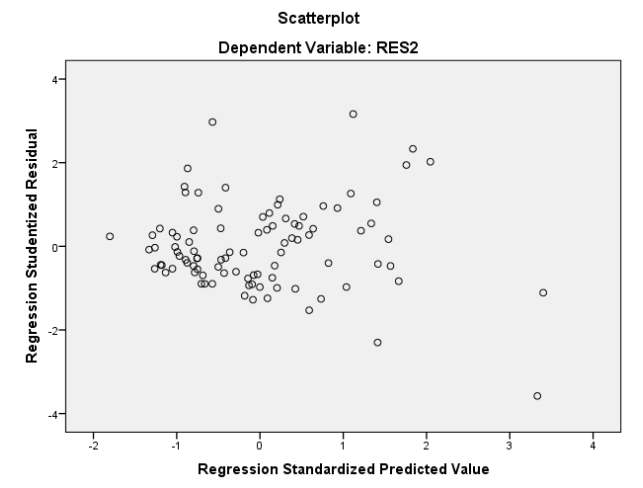

\section{Gambar 3. Hasil Uji Heterokedastisitas}

Sumber: Data diolah SPSS

Berdasarkan pada gambar 3 tersebut di atas, hasil uji grafik scatter plot menunjukkan tidak terjadi heterokedastisitas karena plot tidak membentuk suatu pola dan menyebar secara acak, dengan demikian bias ditarik suatu kesimpulan bahwa tidak terdapat heterokedastisitas.

\section{Uji Analisis Regresi Linear Berganda}

Tabel 3. Hasil AnalisisRegresi Linear Berganda

\begin{tabular}{|c|c|c|c|c|c|c|}
\hline \multirow{3}{*}{\multicolumn{2}{|c|}{ Model }} & \multicolumn{3}{|c|}{ Coefficients } & \multirow{3}{*}{$\mathrm{T}$} & \multirow{3}{*}{ Sig. } \\
\hline & & \multicolumn{2}{|c|}{$\begin{array}{c}\text { Unstandardized } \\
\text { Coefficients } \\
\end{array}$} & \multirow{2}{*}{$\begin{array}{c}\begin{array}{c}\text { Standardized } \\
\text { Coefficients }\end{array} \\
\text { Beta }\end{array}$} & & \\
\hline & & $\mathrm{B}$ & Std. Error & & & \\
\hline \multirow{5}{*}{1} & (Constant) & .021 & .025 & & .843 & .401 \\
\hline & Struktur Modal & .052 & .006 & .705 & 9.270 & .000 \\
\hline & Aktivitas & .126 & .038 & .254 & 3.333 & .001 \\
\hline & Efisiensi Modal & & & & & \\
\hline & Kerja & .000 & .000 & -.080 & -1.000 & .200 \\
\hline
\end{tabular}

a. Dependent Variable: Profitabilitas 
Berdasarkan pada yang ditampilkan pada tabel 3 tersebut di atas, didapatkan hasil persamaan regresi linear berganda sebagaimana berikut ini:

\section{PROFITABILITAS $=0,021+0,052$ STRUKTUR MODAL $+0,126$ AKTIVITAS $+0,000$ EFISIENSI MODAL KERJA}

Berdasarkan pada hasil persamaan tersebut diketahui bahwa nilai a (konstanta) ialah senilai 0.021 , hal ini mengandung arti bahwa apabila variable struktur modal (X1), aktivitas $\left(\mathrm{X}_{2}\right)$, efisiensi modal kerja $\left(\mathrm{X}_{3}\right)$ dan profitabilitas $(\mathrm{Y})$ dianggap konstan, dengan demikian menjelaskan bahwa profitabilitas $(\mathrm{Y})$ perusahaan senilai 0,021 . Koefisien regresi struktur modal $\left(\mathrm{X}_{1}\right)$ sebesar 0,052 , menunjukkan apabila struktur modal mengalami peningkatan senilai $1 \%$ maka kemudian diikuti peningkatan dari profitabilitas senilai 5,2\% dengan asumsi bahwa keseluruhan dari variabel independent yang lain dianggap nol. Koefisien regresi aktivitas $\left(\mathrm{X}_{2}\right)$ senilai 0,126 , menunjukkan apabila struktur modal mengalami peningkatan senilai $1 \%$ maka kemudian diikuti dengan peningkatan pada profitabilitas senilai $12,6 \%$ dengan asumsi bahwa keseluruhan dari variabel independent yang lain dianggap nol. Koefisien regresi efisiensi modal kerja $\left(\mathrm{X}_{3}\right)$ senilai 0,000 , menunjukkan apabila kenaikan struktur modal senilai 1\% dengan demikian akan diikuti oleh profitabilitas yang mengalami penurunan senilai $0 \%$ dengan asumsi bahwa keseluruhan dari variabel independent yang lain dianggap nol.

\section{Koefisien Determinasi Penelitian $\left(\mathbf{R}^{2}\right)$}

Tabel 4. Hasil KoefisienDeterminasi $\left(\mathbf{R}^{2}\right)$

Model Summary

\begin{tabular}{|l|c|r|r|r|}
\hline Model & $\mathrm{R}$ & R Square & $\begin{array}{c}\text { Adjusted R } \\
\text { Square }\end{array}$ & $\begin{array}{c}\text { Std. Error of the } \\
\text { Estimate }\end{array}$ \\
\hline 1 & $.704^{\mathrm{a}}$ & .495 & .479 & .1170123 \\
\hline
\end{tabular}

a. Predictors: (Constant), Efisiensi Modal Kerja, Struktur Modal, Aktivitas

Sumber: Data diolah SPSS

Berdasarkan pada yang ditampilkan di dalam tabel 4 tersebut di atas, diperoleh hasil dari pengujian koefisien determinasi adjusted $\mathrm{R}$ Square $\left(\mathrm{R}^{2}\right)$ senilai 0,479 yang berarti $47.9 \%$ variasi dari variable profitabilitas tersebut telah diterangkan oleh variable independent struktur modal, aktivitas, dan juga efisiensi modal kerja. Sisanya senilai 52,1\% diterangkan oleh variabel independent lainnya yang tidak dimasukkan di dalam penelitian ini, misalnya ialah Current Assets, Net Profit Margin. Serta tingkatan hubungan antara variabel dependent dengan variabel independent secara simultan atau bersama-sama memperlihatkan nilai R senilai 0,704 atau sama dengan 70,4\%.

\section{Pengujian Hipotesis \\ Uji Parsial (Uji t)}

Tabel 5. Hasil Uji t

Coefficients ${ }^{\mathrm{a}}$

\begin{tabular}{|c|c|c|c|c|c|}
\hline \multirow[t]{2}{*}{ Model } & \multicolumn{2}{|c|}{$\begin{array}{l}\text { Unstandardized } \\
\text { Coefficients }\end{array}$} & \multirow{2}{*}{$\begin{array}{c}\begin{array}{c}\text { Standardized } \\
\text { Coefficients }\end{array} \\
\text { Beta } \\
\end{array}$} & \multirow[t]{2}{*}{$\mathrm{T}$} & \multirow[t]{2}{*}{ Sig. } \\
\hline & $\mathrm{B}$ & Std. Error & & & \\
\hline \multirow{4}{*}{$\begin{array}{l}\text { (Constant) } \\
\text { Struktur Modal } \\
\text { Aktivitas } \\
\text { Efisiensi Modal } \\
\text { Kerja }\end{array}$} & .021 & .025 & & .843 & .401 \\
\hline & .052 & .006 & .705 & 9.270 & .000 \\
\hline & .126 & .038 & .254 & 3.333 & .001 \\
\hline & .000 & .000 & -.080 & -1.068 & .288 \\
\hline
\end{tabular}

a. Dependent Variable: Profitabilitas

Sumber: Data diolah SPSS 
Berdasarkan pada yang ditampilkan di dalam tabel 4 tersebut di atas, dijelaskan bahwa variable independent struktur modal $\left(X_{1}\right)$ secara parsial mempunyai nilai $t_{\text {hitung }}$ senilai 9,270 sementara itu untuk nilai tabel yaitu 1,9864 maka $t_{\text {hitung }}>t_{\text {tabel }}$ dengan nilai signifikan 0,000 . Hasil ini menunjukkan $\mathrm{H}_{\mathrm{a}}$ diterima dan $\mathrm{H}_{0}$ ditolak, hal ini berarti bahwa secara parsial variabel independent struktur modal memberikan sumbangan pengaruh yang positif dan juga signifikan terhadap profitabilitas (Y) pada perusahaan yang didaftarkan pada Bursa Efek Indonesia (BEI) untuk periode waktu tahun 2014 sampai dengan tahun 2018.

Variabel aktivitas $\left(\mathrm{X}_{2}\right)$ secara parsial mempunyai nilai thitung senilai 3,333 sedangkan nilai table yaitu 1,9864 dengan demikian bahwa nilai dari $t_{\text {hitung }}>t_{\text {tabel }}$ dengan nilai signifikan 0,001 . Hasil ini menunjukkan $\mathrm{H}_{\mathrm{a}}$ diterima dan $\mathrm{H}_{0}$ ditolak, hal ini berarti bahwa variabel independent struktur modal memberikan sumbangan pengaruh yang positif dan juga signifikan terhadap profitabilitas (Y) pada perusahaan yang didaftarkan pada Bursa Efek Indonesia (BEI) untuk periode waktu tahun 2014 sampai dengan tahun 2018. Variabel efisiensi modal kerja $\left(\mathrm{X}_{3}\right)$ secara parsial mempunyai nilai $\mathrm{t}_{\text {hitung }}$ senilai -1,068 sedangkan nilai $t_{\text {table }}$ yaitu 1,9864 dengan demikian bahwa $t_{\text {hitung }}<t_{\text {tabel }}$ dengan nilai signifikan 0,288. Hasil ini menunjukkan $\mathrm{H}_{a}$ ditolak dan $\mathrm{H}_{0}$ diterima, hal ini berarti bahwa secara parsial struktur modal memberikan sumbangan pengaruh yang negatif dan signifikan terhadap profitabilitas (Y) pada perusahaan yang didaftarkan pada Bursa Efek Indonesia (BEI) untuk periode waktu tahun 2014 sampai dengan tahun 2018.

\section{Uji Simultan (Uji F)}

\section{Tabel 6. Hasil Uji F}

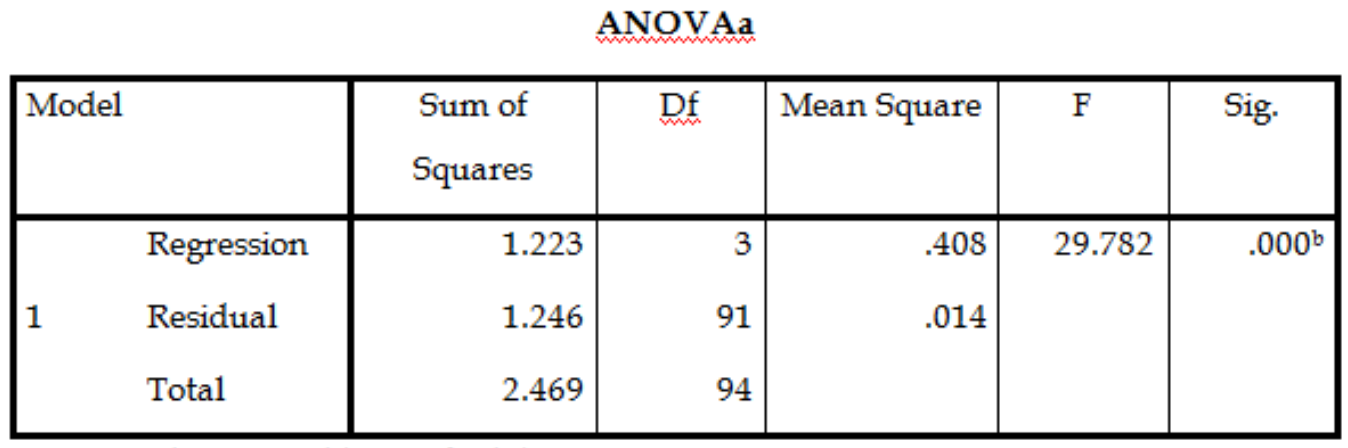

a. Dependent Variable: Profitabilitas

b. Predictors: (Constant), Efisiensi Modal Kerja, Struktur modal, Aktivitas

\section{Sumber: Data diolah SPSS}

Berdasarkan table diatas, diperoleh nilai $\mathrm{F}_{\text {hitung }}$ sebesar 29,782 $>\mathrm{F}_{\text {tabel }}$ yaitu 2,70 dengan nilai signifikan senilai 0,000 . Dengan demikian bias ditarik suatu kesimpulan bahwa $\mathrm{H}_{0}$ ditolak dan sedangkan untuk $\mathrm{H}_{\mathrm{a}}$ diterima. Hal memiliki arti bahwa secara bersama-sama variable bebas yaitu struktur modal, aktivitas, dan efisiensi modal kerja secara simultan memberikan sumbangan pengaruh yang positif dan juga signifikan terhadap variable terikat profitabilitas $(\mathrm{Y})$ pada perusahaan yang didaftarkan pada Bursa Efek Indonesia (BEI) untuk periode waktu tahun 2014 sampai dengan tahun 2018.

\section{Pengaruh Struktur Modal Terhadap Profitabilitas}

Kesimpulan dari hasil pengujian hipotesis adalah secara parsial struktur modal memberikan sumbangan pengaruh yang signifikan terhadap variable terikat profitabilitas (Y) pada perusahaan yang didaftarkan pada Bursa Efek Indonesia (BEI) untuk periode waktu tahun 2014 sampai dengan tahun 2018.

Hasil dari pelaksanaan penelitian ini sejalan dengan teori yang dikemukakan oleh Sri Dwi Ari Ambarwati (2010:2), "Perusahaan harus mengambil keputusan permodalan yang paling optimal 
sehingga antara utang dan ekuitas benar-benar kombinasi yang dapat menghasilkan keuntungan bagi perusahaan yang akhirnya memaksimalkan laba perusahaan."

Hasil dari pelaksanaan penelitian ini senada dengan hasil dari pelaksanaan penelitian yang dilaksanakan oleh jurnal Yoyo Sudaryo, IkaYanuar Pratiwi (2016) dengan judul, "Pengaruh Struktur Modal dan Likuiditas Terhadap Profitabilitas dan Dampaknya Terhadap Kinerja (Studi Kasus pada Perusahaan Property, Real Estate and Building Construction yang Terdaftar di BEI LQ45 Periode 2007-2014)".

\section{Pengaruh Aktivitas Terhadap Profitabilitas}

Kesimpulan dari hasil dari pengujian hipotesis adalah secara parsial struktur modal memberikan sumbangan pengaruh yang positif dan juga signifikan terhadap profitabilitas pada perusahaan sektor infrastruktur, utilitas dan transportasi yang terdaftar di bursa efek Indonesia tahun 2014 - 2018. Hasil dari pelaksanaan penelitian ini sejalan dengan teori yang dikemukakan oleh Kasmir (2012:85),"Semakin tinggi rasio aktivitas maka menunjukkan perusahaan telah mampu memaksimalkan aktiva perusahaan untuk meningkatkan penjualan. Dengan tingkat penjualan yang tinggi diharapkan perusahaan mampu menghasilkan laba yang tinggi pula”. Hasil dari pelaksanaan penelitian ini senada dengan hasil dari pelaksanaan penelitian yang dilaksanakan oleh jurnal Muhammad Halil (2014) dengan judul, "Pengaruh Rasio Leverage dan Aktivitas Terhadap Profitabilitas pada Perusahaan Ritel Yang Terdaftar Di Bursa Efek Indonesia (BEI) Periode 20092012".

\section{Pengaruh Efisiensi Modal Kerja Terhadap Profitabilitas}

Kesimpulan dari hasil dari pengujian hipotesis adalah secara parsial struktur modal tidak memberikan sumbangan pengaruh yang positif dan juga tidak signifikan terhadap profitabilitas pada perusahaan sektor infrastruktur, utilitas dan transportasi yang terdaftar di Bursa Efek Indonesia tahun $2014-2018$.

Hasil dari pelaksanaan penelitian ini sejalan dengan teori yang dikemukakan oleh Sri Dwi Ari Ambarwati (2010:111), "Modal kerja merupakan suatu aktiva lancar yang digunakan dalam operasi perusahaan, yang memerlukan pengelolaan yang baik dari manajer agar operasional perusahaan lebih optimal dan efisien. Dengan kata lain, modal kerja adalah modal yang seharusnya ada dalam perusahaan sehingga operasional perusahaan lebih lancar dan efisien untuk menghasilkan laba".

Hasil dari pelaksanaan penelitian ini senada dengan hasil dari pelaksanaan penelitian yang dilaksanakan oleh jurnal Elly Octavianty, Defi Jumadil Syahputra (2015), dengan judul, "Pengaruh Efisiensi Modal Kerja dan Likuiditas Terhadap Profitabilitas Pada Perusahaan Subsektor Farmasi Yang Terdaftar Di Bursa Efek Indonesia (BEI)”.

\section{KESIMPULAN}

Berdasarkan hasil penelitian dan pembahasan pada bab-bab sebelumnya, maka dapat diambil beberapa kesimpulan yaitu secara parsial struktur modal memberikan sumbangan pengaruh yang positif dan juga signifikan terhadap keuntungan atau profitabilitas yang diperoleh oleh perusahaan sektor infrastruktur, utilitas dan transportasi yang didaftarkan pada Bursa Efek Indonesia (BEI) untuk periode waktu tahun 2014 sampai dengan tahun 2018 tingkat signifikansi 0,000. Secara parsial aktivitas, modal kerja dan struktur modal memberikan sumbangan pengaruh yang positif dan juga signifikan terhadap keuntungan atau profitabilitas yang diperoleh oleh perusahaan sektor infrastruktur, utilitas dan transportasi yang didaftarkan pada Bursa Efek Indonesia (BEI) untuk periode waktu tahun 2014 sampai dengan tahun 2018 tingkat signifikansi 0,001. Secara simultan struktur modal, aktivitas dan efisiensi modal kerja memberikan sumbangan pengaruh yang positif dan juga signifikan terhadap keuntungan atau profitabilitas yang diperoleh oleh perusahaan sektor infrastruktur, utilitas dan transportasi yang didaftarkan pada Bursa Efek Indonesia (BEI) untuk periode waktu tahun 2014 sampai dengan tahun 2018 tingkat signifikansi 0,000. 


\section{REFERENSI}

Ambarwati, Sri Dwi Ari. 2010. Manajemen Keuangan Lanjut, Yogyakarta: GrahaIlmu

Bungin, M. Burhan. 2011. Metode Penelitian Kuantitatif. EdisiKedua. Jakarta: PenerbitKencana.

Fahmi, Irham. 2018. Pengantar Manajemen Keuangan: Teori dan Soal Jawab. Cetakan Keenam. Bandung: Penerbit Alfabeta.

Halil, Muhammad. 2014. "Pengaruh Rasio Leverage dan Aktivitas Terhadap Profitabilitas pada Perusahaan Ritel Yang Terdaftar Di Bursa Efek Indonesia (BEI) Periode 2009-2012".

Hery. 2016. Financial Ratio for Business. Jakarta: Penerbit Grasindo.

Hidayati, Ulil. 2016. "Analisis Pengaruh Efisiensi Modal Kerja, Leverage, Umur Perusahaan, dan Family Control Terhadap Profitabilitas Perusahaan Manufaktur Yang Terdaftar Di Bursa Efek Indonesia”, Skripsi, Fakultas Ekonomi dan BisnisUniversitas Sumatera Utara, Medan.

Kamaliah, Nazrial Akbar, dan Lexinta Kinanti, 2009. "Analisis Pengaruh Rasio Aktivitas, Leverage Keuangan, Ukuran dan Umur Perusahaan Terhadap Profitabilitas Perusahaan Wholesale and Retail Trade yang Terdaftar Di Bursa Efek Indonesia”, Jurnal Ekonomi, Vol.17, No. 3.

Kasmir. 2012. Analisis Laporan Keuangan. Jakarta: PT. Raja Grafindo Persada.

Kasmir. 2018. Analisis Laporan Keuangan. Cetakan kelima. Jakarta: PT. Raja Grafindo Persada.

Limbong, Jumaidah Apriani, 2017. "Pengaruh Efisiensi Manajemen Modal Kerja Terhadap Profitabilitas (Studi Pada Perusahaan Farmasi BUMN dan BUMS di Bursa Efek Indonesia Periode 2010-2014)", Skripsi Fakultas Ekonomi Dan Bisnis Universitas Sumatra Utara Medan.

Najmudin. 2011. Manajemen Keuangan dan Aktualisasi Syar'iyyah Modern. Yogyakarta: Penerbit Andi.

Octavianty, Elly dan Defi Jumadil Syahputra. 2015. "Pengaruh Efisiensi Modal Kerja dan Likuiditas Terhadap Profitabilitas Pada Perusahaan Subsektor Farmasi Yang Terdaftar Di Bursa Efek Indonesia (BEI)", Jurnal Ilmiah Akuntansi Fakultas Ekonomi, Vol.1, No.2.

Sartono, Agus. 2010. Manajemen Keuangan: Teori dan Aplikasi. Edisi Keempat. Yogyakarta: BPFE Yogyakarta.

Sudaryo, Yoyo dan Yanuarpratiwi, 2016. "Pengaruh Struktur Modal dan Likuiditas Terhadap Profitabilitas dan Dampaknya Terhadap Kinerja Keuangan", Jurnal Indonesia Membangun, Vol.2, No.1.

Suharso, Puguh. 2009. Metode Penelitian Kuantitatif UntukBisnis: Pendekatan Filosofi dan Praktis. Jakarta: PT. Indeks.

Sujarweni, V. Wiratna. 2018. Manajemen Keuangan: Teori, Aplikasi dan Hasil Penelitian. Yogyakarta: Pustaka Baru. 